\title{
Reproductive Energetics of the African Reed Frogs, Hyperolius viridiflavus and Hyperolius marmoratus
}

\section{T. Ulmar Grafe* \\ Richard Schmuck $†$ \\ K. Eduard Linsenmair}

Zoologisches Institut, Röntgenring 10, W-8700 Würzburg, Germany

Accepted 6/28/91

\begin{abstract}
We investigated the reproductive energetics of two reed frogs, Hyperolius viridiflavus ommatostictus and Hyperolius marmoratus taeniatus. Rates of $\mathrm{CO}_{2}$ release of calling male $\mathrm{H}$. viridiflavus ommatostictus reached values of $0.28-1.05 \mathrm{~mL} / \mathrm{g} \cdot \mathrm{b}$ equivalent to an $\mathrm{O}_{2}$ consumption of $0.38-1.44 \mathrm{~mL} \mathrm{O} / \mathrm{g} \cdot \mathrm{b}$. Mean estimated $\mathrm{O}_{2}$ consumption was $1.40 \mathrm{~mL} / \mathrm{g} \cdot \mathrm{b}$ at an average call rate of 5,400 calls/b. The estimated net cost of calling was $33 \mathrm{~J} / \mathrm{h}$ for a $1.5 \mathrm{-g}$ male. Lactate levels were bigher after calling than after resting, but this was due to bigher lactate concentrations in the limbs than in the rest of the body containing the trunk muscles used for calling. Thus, anaerobic metabolism does not contribute significantly to calling energetics. Assimilation efficiencies of juvenile $\mathrm{H}$. marmoratus taeniatus and adult males and females of both species were $81.4 \%-87.7 \%$. The energy content of an average clutch was $3.73 \mathrm{~kJ}$ and $2.84 \mathrm{~kJ}$ for $\mathrm{H}$. viridiflavus ommatostictus and $\mathrm{H}$. marmoratus taeniatus, respectively. Net conversion efficiencies of females of both species measured directly as the actual proportion of energy invested in eggs were about 29\% and are the first measurements of this kind in ampbibians. Whole-body lipid content decreased significantly over the course of a simulated breeding season in male but not in female $\mathrm{H}$. marmoratus taeniatus, suggesting that males may bave difficulties replenishing fat stores while engaging in reproductive activity even under ad lib. feeding conditions.
\end{abstract}

\section{Introduction}

Questions concerning resource acquisition and energy allocation are of general interest in evolutionary biology. All organisms face the issue of how

\footnotetext{
* Present address: Section of Neurobiology and Behavior, Mudd Hall, Cornell University, Ithaca, New York 14853 2702.

†Present address: Institut fur Ökologie, Bayer AG Manheim, W-5090 Leverkusen, Germany.
}

Physiological Zoology 65(1):153-171. 1992. (c) 1992 by The University of Chicago.

All rights reserved. 0031-935X/92/6501-90142\$02.00 
to partition energy between the demands of growth, maintenance (repair, defense, and storage), and reproduction. Measurements of the energetic costs of reproduction are critical to understanding important facets of life-history tactics (Stearns 1976) and patterns of sexual selection (Trivers 1972; Halliday 1987). In addition, studies on the energetics of reproduction have contributed to attempts to directly link performance with fitness and have shed light on the underlying physiological constraints on behavior (Pough 1989).

Males and females often show considerable differences in their methods of maximizing reproductive success and thus differ in many aspects of their life-history patterns. In species lacking parental care, reproductive effort through direct investment in offspring generally is very high in females, whereas males invest mainly in mating effort (Maynard Smith 1958). Most anurans show this fundamental difference between male and female investment (Wells 1977).

In anurans, female reproductive expenditure is expected to be higher than in males because of the high investment in gametes by females. Recent studies have shown, however, that males can incur very high metabolic costs during vocalization (Bucher, Ryan, and Bartholomew 1982; Taigen and Wells 1985; Taigen, Wells, and Marsh 1985; Prestwich, Brugger, and Topping 1989; Wells and Taigen 1989). Other studies have demonstrated that males may be severely energy limited in their mating activities, leading to reduced growth rates (see, e.g., Woolbright 1985; Given 1988). Males also may exhibit alternative mating tactics according to energetic status (see, e.g., MacNally 1981; Robertson 1986).

This paper gives a quantitative assessment of the reproductive effort of male and female Hyperolius viridiflavus ommatostictus and Hyperolius marmoratus taeniatus. The taxonomic status of these frogs is a matter of dispute. We follow the more recent revision put forth by Poynton (1985) and Poynton and Broadley (1987) of the classification by Schiøtz (1971, 1975). Both species appear to be closely related and are physiologically and behaviorally very similar. We also measured the investment of $H$. mar. moratus taeniatus juveniles in growth to better evaluate the reproductive effort seen in adults.

We attempt to answer the following questions: (1) What is the energy expenditure of calling males and is there an anaerobic contribution to calling? (2) What proportion of assimilated energy do females invest in reproduction? (3) Do lipid stores decrease as a result of reproductive behavior?

Hyperolius viridiflavus ommatostictus and $H$. marmoratus taeniatus (Hyperoliidae) are small reed frogs with average body masses of $2.0 \mathrm{~g}$ and $1.6 \mathrm{~g}$, respectively. The life histories of both species, as well as their phys- 
iology and behavior, are strongly influenced by the environmental fluctuations of the dry and wet seasons of the African savannas (Withers, Louw, and Nicholson 1982; Geise and Linsenmair 1986, 1988; Kobelt and Linsenmair 1986; Schmuck, Kobelt, and Linsenmair 1988; Schmuck and Linsenmair 1988). During the breeding season males form choruses at bodies of water, where they advertise for females (see also Telford 1985). Males maintain individual spacing in the chorus and defend calling sites through intense and prolonged combat (see also Wager 1965; Stewart 1967; Telford 1985; T. U. Grafe, personal observations). Females approach males and initiate amplexus. Eggs are laid on vegetation under water. Females produce multiple clutches during the course of the breeding season (Richards 1977; Geise 1987; Telford and Dyson 1990) that typically lasts several months (Telford 1985).

\section{Material and Methods}

All frogs used in the experiments were offspring of animals obtained from a commercial supplier and had been reared in the laboratory. After metamorphosis, juvenile frogs were initially kept under humid conditions, then reared under dry-season conditions (Geise and Linsenmair 1986) for 4-6 mo, and finally transferred to spacious terraria with more humid conditions, where they matured and breeding activity took place (for details see Geise 1987; Grafe 1988). Frogs were fed Drosopbila, Musca, or Lucilia on a daily schedule.

\section{Aerobic Energy Metabolism}

We measured $\mathrm{CO}_{2}$ release in an open-flow-through system with an infrared gas analyzer (Unor $4 \mathrm{~N}, \mathrm{Fa}$. Maihak AG.; Geise 1987) at $25^{\circ} \mathrm{C}$ and with an air-flow rate of $16 \mathrm{~L} / \mathrm{h}$. At $16 \mathrm{~L} / \mathrm{h}$ sensitivity of the analyzer was $0.77 \mathrm{ppm}$ per scale of $1 \mathrm{~mm}$. Oxygen consumption was calculated from $\mathrm{CO}_{2}$ release by assuming a respiratory quotient (RQ) of 0.73 . This estimate is based on RQ measurements of calling male Hyperolius marmoratus broadleyi collected in the field (T. U. Grafe, unpublished data).

At early night hours, we removed males from amplexus and transferred them into a respiration chamber of approximately $100 \mathrm{~mL}$ in volume and stimulated them to call using a playback of a $H$. viridiflavus ommatostictus chorus. Only amplectant males were used because they showed a high calling motivation. We measured $\mathrm{CO}_{2}$ release of resting males at late-night hours after calling activity had ceased. During measurements of resting me- 
tabolism males were inactive, maintaining a water-conserving posture. The respiration chamber was surrounded by a cardboard box with a small observation slit and illuminated with a dim red light, thus allowing undisturbed observations of the frogs. The number of calls each male produced was counted. We did not record call duration. Measurements of $\mathrm{CO}_{2}$ release of calling and resting frogs were evaluated after an acclimation time in the chamber of $30 \mathrm{~min}$ and $120 \mathrm{~min}$, respectively. A shorter acclimation time was used for calling frogs because calling never lasted more than $1 \mathrm{~h}$ after frogs had been placed in the chamber. All frogs had been fed ad lib. prior to measurements.

For an estimate of the number of calls a male produces at night we monitored frogs in laboratory terraria. The advertisement calls produced by the reed frogs Hyperolius viridiflavus and Hyperolius marmoratus are simple one-note calls of high-peak sound intensity $(105-110 \mathrm{~dB}$ at $50 \mathrm{~cm}$; Passmore 1981), relatively fixed duration ( $70 \mathrm{~ms}$; Telford 1985), and vary within species in frequency and call rate (Schiøtz 1975; Telford 1985; Grafe 1988). The number of calls a male produced per night in the laboratory was determined using a microphone (Aiwa CM-Z3) attached to a chart-level recorder (Colora Recorder 600) interconnected with an oscilloscope (Gould OS 3300 B) for optimal visual recording and amplification.

\section{Anaerobic Energy Metabolism}

The contribution of anaerobic energy expenditure to calling and forced activity was measured by determining the lactic acid content of whole-body homogenates. Measurements after forced activity were conducted for an assessment of lactic acid buildup in males engaged in fighting activity, with the assumption that the same muscles are being used during both activities. We induced forced activity by rotating frogs for $5 \mathrm{~min}$ in a small chamber by hand. Males were apparently exhausted after this time period. We tested males in the afternoon during the normally inactive part of the day to insure that lactic acid buildup was not caused by previous activity. We adjusted rotation speed to keep frogs moving constantly. All frogs were shock frozen in liquid $\mathrm{N}_{2}$ immediately after exercise, calling, or resting. Limbs were removed from six frogs that had called for $2-3$ h as well as for two resting frogs, and limbs and the rest of the body homogenized separately. This procedure was followed to separate the contributions of trunk and laryngeal muscles (used for calling) and leg muscles to anaerobic energy metabolism. Samples were homogenized in chilled $8 \%$ perchloric acid and centrifuged for $10 \mathrm{~min}$ at $1,500 \mathrm{rpm}$. We determined lactate concentration using a Sigma- 
diagnostic lactate kit (826-UV) and recorded absorbance at $340 \mathrm{~nm}$ with a spectrophotometer (Uvikon 720 LC, Kontron).

\section{Assimilation and Conversion Efficiencies}

In assimilation efficiency (assimilated energy/consumed energy $=A / C$ ) trials, $H$. viridiflavus ommatostictus and $H$. marmoratus taeniatus were kept individually in $20 \times 40 \times 20-\mathrm{cm}$ terraria equipped with clay floors and planted with a herbaceous plant. Each frog was fed 20 Musca daily. Flies not eaten were removed the next day. Fifty to 100 Musca from each day's supply and feces for each animal were dried at $60^{\circ} \mathrm{C}$ to constant mass and the energy content determined with a bomb calorimeter (Morat MK 200). Assimilation was calculated as $A=C-F$, where $F$ is the fecal excretory products. Urine constituted less than $5 \%$ of fecal caloric value (R. Schmuck, unpublished data), and therefore urinary excretion was not measured in experimental animals.

The net conversion efficiency (production/assimilated energy $=P / A$ ) was determined for juvenile $H$. marmoratus taenitus (6-16 wk old and kept under wet-season conditions) that had been fed with Musca ad lib. for 32 $\mathrm{d}$ at a day-night temperature cycle of $30^{\circ}-20^{\circ} \mathrm{C}$. We kept juvenile frogs in bare, unplanted containers. Snout-vent length of each frog was measured at the beginning of the experiment, and its initial composition of fat, protein, and carbohydrate were determined with calibration curves between body length and the fat, protein, and carbohydrate content obtained from 28 juvenile frogs of the same stock. After $32 \mathrm{~d}$ the fat, protein, and carbohydrate content of each frog was determined by carcass analysis and the initial values for each frog subtracted to obtain incremental values (Schmuck 1989).

To ascertain the proportion of assimilated energy that females invest in egg production, three $H$. viridiflavus ommatostictus and three $H$. marmoratus taeniatus females were isolated immediately after deposition of a clutch and $A / C$ determined until the next clutch was laid. Clutches were dried at $60^{\circ} \mathrm{C}$ to constant mass and energy content determined in a bomb calorimeter (Morat MK 200). This yielded an average dry mass-specific energy of $24 \mathrm{~J} /$ $\mathrm{mg}$ for both species. This value was used to calculate the average clutch energy content of a larger sample of clutches for a less biased estimate. Dry mass for these clutches was estimated from the dry mass of a random sample of 25-100 eggs from each clutch. Females were weighed and snout-vent lengths measured at regular intervals, including immediately after egg deposition.

To determine whether lipid stores were depleted during reproductive activity, we examined the whole-body lipid contents of a random sample 
of breeding male and female $H$. marmoratus taeniatus at three time periods: at the beginning, at $8 \mathrm{wk}$ into, and at the end of the 3 -mo simulated breeding season. All frogs had been synchronized to start breeding activity within the same week. Ovaries were removed in females prior to carcass analysis.

\section{Carcass Analysis}

Carcasses were analyzed to determine the conversion efficiencies $(P / C$ and $P / A$ ) of juveniles and the lipid content of adult breeding frogs. Whole-body lipid content is probably a better indicator of utilizable fat stores than just the fat bodies (Fitzpatrick 1976) because fat stores can be found elsewhere in the body, especially subcutaneously. Carcasses dried at $50^{\circ} \mathrm{C}$ until constant mass were extracted in hot $\left(50^{\circ} \mathrm{C}\right)$ chloroform-methanol solution $(2: 1)$ for $1-2 \mathrm{~h}$. This procedure extracts utilizable neutral lipids (triglycerides) but in addition it removes fixed lipids (membrane lipids) that are not utilizable stores and therefore results in slightly overestimated values of fat stores (Dobush, Ankney, and Krementz 1985). Mass differences of dried carcasses before and after extraction yield body lipid content. Carbohydrates were removed from the lipid-free carcasses by digestion in $5 \%$ perchloric acid. Subsequent incineration of the dried undigestible constituents reveals the protein fraction.

Correction of the carbohydrate fraction was necessary because of the partial loss of inorganic solids when removing perchloric acid from the extractor (two washings with bidistilled water). For this purpose, we determined the ash contents of different-sized juvenile frogs from the same stock and used these to ascertain the total ash fraction of the test animals. Differences between this mean value and the inorganic solids remaining after incineration of lipid-carbohydrate-free carcasses were thought to equal solids removed with perchloric acid and washing solutions.

\section{Data Analyses}

For pairwise comparisons the Mann-Whitney $U$-test was used and for experimentwise comparisons we employed the Studentized range using har monic means (Snedecor and Cochran 1980). We used least-squares-regression analysis to determine the relationship between call rate and $\mathrm{O}_{2}$ consumption. Results are expressed as means \pm SDs. The level of statistical significance was set at $P<0.05$. 


\section{Results}

Aerobic Metabolism

Males of both species called $2-4 \mathrm{hr}$ a night with short interruptions only, averaging 9,560 $\pm 4,252$ (Hyperolius viridiflavus ommatostictus, $n=12$ ) and 10,055 $\pm 3,029$ (Hyperolius marmoratus taeniatus, $n=21$ ) calls per night, with a call repetition rate of $3,600-7,200$ calls $/ \mathrm{h}$. Call rate and duration per call did not differ significantly between the species ( $U$-test, $P>0.05$ ).

Rates of $\mathrm{CO}_{2}$ release increased linearly with call rate in $H$. viridiflavus ommatostictus, as did estimated values of $\mathrm{O}_{2}$ consumption (fig. 1). All experimental animals called at a lower rate than unrestrained animals. At an average call rate of 5,400 calls/h shown by unrestrained males, $\mathrm{O}_{2}$ consumption is predicted to reach values of $1.40 \mathrm{~mL} / \mathrm{g} \cdot \mathrm{h}$ (table 1 ). There was no significant difference in $\dot{\mathrm{V}} \mathrm{CO}_{2 \text { rest }}$ or $\dot{\mathrm{V}}_{2 \text { rest }}$ between either male and female H. marmoratus taeniatus or between males of the two species ( $U$-test, $P$ $>0.05$; table 1 ).

\section{Anaerobic Metabolism}

Whole-body lactate concentrations were significantly higher in frogs after forced activity than after resting or calling ( $U$-test, $P<0.001$; table $2)$. However, lactic acid concentration of male $H$. viridiflavus omma. tostictus excluding their limbs (rest of body) was not significantly dif-

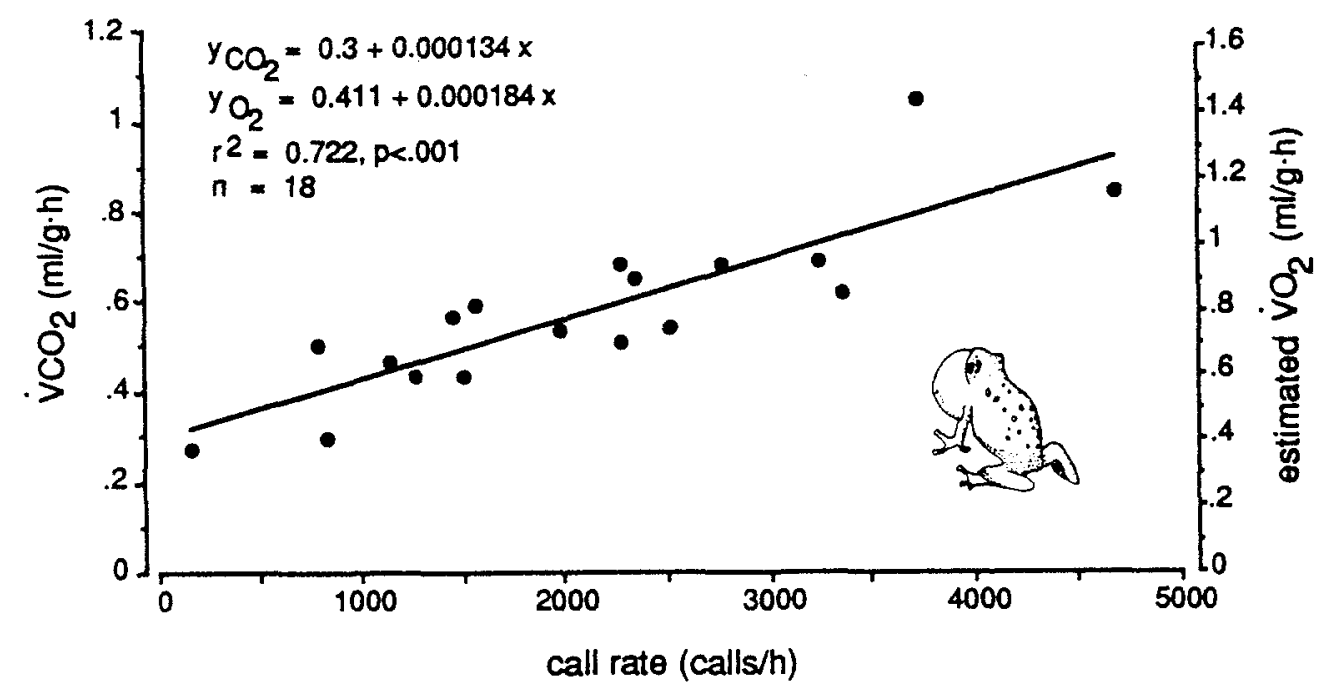

Fig. 1. Relationship of $\mathrm{CO}_{2}$ release and $\mathrm{O}_{2}$ consumption of male Hyperolius viridiflavus ommatostictus to call rate; $\mathrm{CO}_{2}$ release was converted to $\mathrm{O}_{2}$ consumption using an $R Q$ of 0.73 . 
TABLE 1

Carbon dioxide release and estimated $\mathrm{O}_{2}$ consumption of Hyperolius viridiflavus and Hyperolius marmoratus at rest and wbile calling

\begin{tabular}{lll}
\hline $\begin{array}{ll}\dot{\mathrm{V}}_{\mathrm{CO}_{2}} \\
(\mathrm{~mL} / \mathrm{g} \cdot \mathrm{h})\end{array}$ & $\begin{array}{l}\dot{\mathrm{V}}_{2} \\
(\mathrm{~mL} / \mathrm{g} \cdot \mathrm{h})\end{array}$ & $\begin{array}{l}\text { Mass } \\
(\mathrm{g})\end{array}$ \\
\hline
\end{tabular}

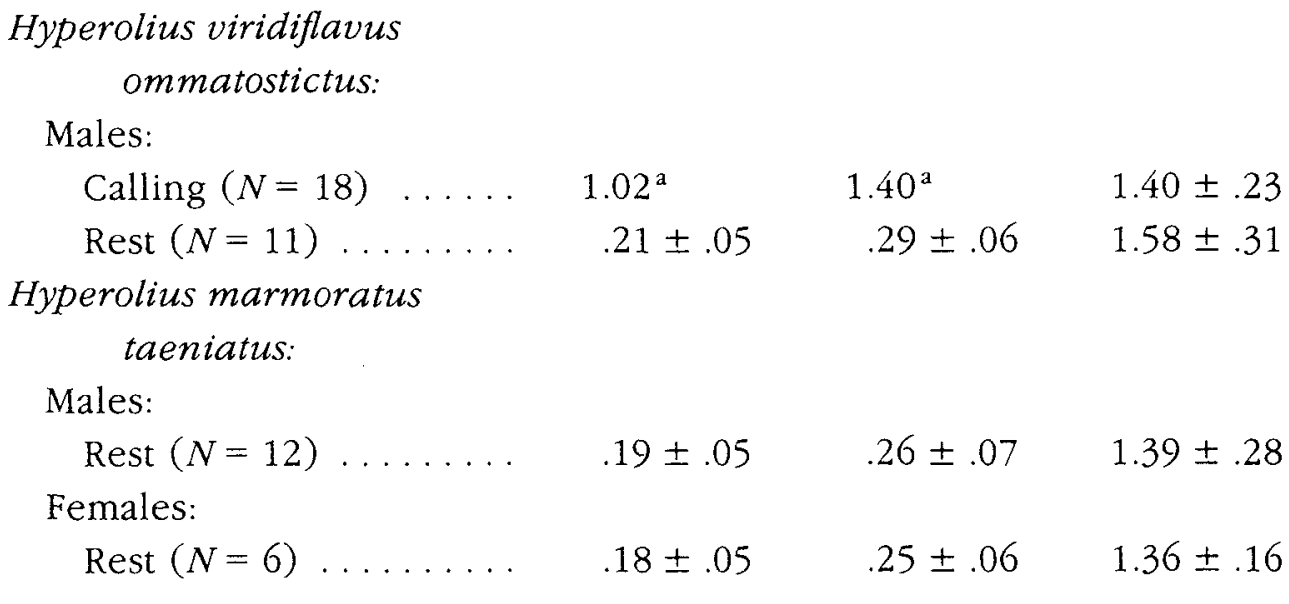

Note. Values are means $\pm S D$. The $\dot{\mathrm{VO}}_{2}$ values are obtained from $\dot{\mathrm{V}}_{\mathrm{CO}_{2}}$ with an assumed $\mathrm{RQ}$ of 0.73 .

${ }^{a}$ Values are calculated for a calling rate of 5,400 calls $/ \mathrm{h}$ of 18 frogs with the regression equations in fig. 1.

ferent between resting and calling individuals ( $U$-test, $P>0.05$; table 2 ). Therefore, there seems to be no significant anaerobic contribution to vocalization.

\section{Assimilation and Conversion Efficiencies}

Assimilation efficiencies did not change significantly in females of either species after termination of egg production (postreproductive) under unchanged laboratory conditions (Studentized range, $P>0.05$; table 3 ). There was also no significant difference in $A / C$ between males and females of either species (Studentized range, $P>0.05$ ). The ratio $A / C$ was significantly lower in juvenile than in adult $H$. marmoratus taeniatus (Studentized range, $P<0.01)$. No significant differences were found in the conversion efficiencies between the sexes of adults of both species of reed frogs (Studentized range, $P>0.05)$. 
TABLE 2

Lactic acid concentrations of male Hyperolius viridiflavus ommatostictus after resting, calling, and forced activity

\begin{tabular}{|c|c|c|c|}
\hline \multirow[b]{2}{*}{ Behavior } & \multicolumn{3}{|l|}{$\begin{array}{l}\text { Lactate } \\
(\mathrm{mg} / \mathrm{g})\end{array}$} \\
\hline & Whole Body & Limbs & Rest of Body \\
\hline Resting & $.344 \pm .104(6)$ & $.487 \pm .064(2)$ & $.284 \pm .086(2)$ \\
\hline Calling $(2-3 \mathrm{~h})$ & $.460 \pm .113(6)$ & $.836 \pm .348(6)$ & $.304 \pm .100(6)$ \\
\hline Forced activity $(5 \mathrm{~min})$ & $1.054 \pm .380(10)$ & 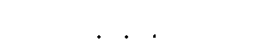 & \\
\hline
\end{tabular}

Note. Values are means \pm SD. Numbers in parentheses are sample sizes. Ellipses indicate no data available.

\section{Energy Budgets}

Average intervals between clutches were $15.6 \pm 4.6 \mathrm{~d}(n=15)$ for $H$. viridiflavus ommatostictus and $15.5 \pm 5.6 \mathrm{~d}(n=29)$ for $H$. marmoratus taeniatus. Females laid $0-12$ clutches during the breeding season (4-6 mo) that was simulated in the laboratory. Clutch sizes averaged $331 \pm 137$ $(n=31 ; 106-734)$ for $H$. viridiflavus ommatostictus and $272 \pm 121$ ( $n$ $=40 ; 86-576)$ for $H$. marmoratus taeniatus. The energy content of an average clutch was $3.73 \pm 1.55 \mathrm{~kJ}(n=31 ; 1.20-8.28 \mathrm{~kJ})$ for $H$. viridiflavus ommatostictus and $2.84 \pm 1.48 \mathrm{~kJ}(n=39 ; 0.79-6.64 \mathrm{~kJ})$ for $H$. marmoratus taeniatus.

The energy budgets of $H$. viridiflavus ommatostictus and $H$. marmoratus taeniatus females are shown in figure 2 . Three $H$. viridiflavus ommatostictus females deposited five clutches with an average energy content of $303 \pm 69 \mathrm{~J} / \mathrm{d}$ or $29.9 \% \pm 10.5 \%$ of the assimilated energy (table $3)$. Nine clutches deposited by three $H$. marmoratus taeniatus females averaged $250 \pm 65 \mathrm{~J} / \mathrm{d}$ or $28.9 \% \pm 6.5 \%$ of the assimilated energy (table $3)$. We did not detect any growth or mass increase after successive egg deposition. Female $H$. marmoratus taeniatus that were producing clutches did not have significantly different conversion efficiencies ( $P / A$ and $P / C$ ) from juveniles ( $U$-test, $P>0.05$; table 3 ). The percent total body lipid content decreased significantly over the course of the breeding season in calling male $H$. marmoratus taeniatus, but not in females (table 4). 
TABLE 3

Assimilation efficiencies (A/C) and conversion efficiencies (gross $=\mathrm{P} / \mathrm{C}$; net $=\mathrm{P} / \mathrm{A}$ ) in percent for Hyperolius viridiflavus and Hyperolius marmoratus

\begin{tabular}{|c|c|c|c|}
\hline & $A / C$ & $P / C$ & $P / A$ \\
\hline \multicolumn{4}{|l|}{ Hyperolius viridiflavus } \\
\hline \multicolumn{4}{|l|}{ ommatostictus: } \\
\hline \multicolumn{4}{|l|}{ Females: } \\
\hline Gravid & $85.6 \pm 1.7(5)$ & $25.5 \pm 8.7(5)$ & $29.9 \pm 10.5(5)$ \\
\hline Postreproductive & $84.6 \pm 5.3(4)$ & & . \\
\hline Males $\ldots \ldots \ldots$. & $87.7 \pm 1.1(2)$ & & . \\
\hline \multicolumn{4}{|c|}{ Hyperolius marmoratus } \\
\hline \multicolumn{4}{|l|}{ taeniatus: } \\
\hline Juveniles & $81.4 \pm 2.4(14)$ & $23.3 \pm 4.0(14)$ & $28.7 \pm 5.2(14)$ \\
\hline \multicolumn{4}{|l|}{ Females: } \\
\hline Gravid & $84.3 \pm 2.2(9)$ & $24.3 \pm 5.4(9)$ & $28.9 \pm 6.5(9)$ \\
\hline Postreproductive & $86.3 \pm 2.7(6)$ & . & . \\
\hline Males & $84.9 \pm 2.9(3)$ & & \\
\hline
\end{tabular}

Note. Values are means \pm SD. Numbers in parentheses are sample sizes. Conversion efficiencies are in the form of growth for juveniles and as egg production for females. Ellipses indicate no data are available.

\section{Discussion}

\section{Energetic Costs of Calling}

This study has shown that the estimated rate of $\mathrm{O}_{2}$ consumption at average calling rates for Hyperolius viridiflavus ommatostictus $\left(1.40 \mathrm{~mL} \mathrm{O}_{2} / \mathrm{g} \cdot \mathrm{h}\right)$ is similar in magnitude to rates in other very active callers, such as Physalaemus pustulosus (0.91 $\mathrm{mL} \mathrm{O}_{2} / \mathrm{g} \cdot \mathrm{h}$; Bucher et al. 1982), Hyla versicolor (1.70 $\mathrm{mL} \mathrm{O}_{2} / \mathrm{g} \cdot \mathrm{h}$; Taigen and Wells 1985$)$, Hyla crucifer $(1.51 \mathrm{~mL} \mathrm{O} / \mathrm{g} \cdot \mathrm{h}$; Taigen et al. 1985), Hyla microcephala (1.70 $\mathrm{mL} \mathrm{O}_{2} / \mathrm{g} \cdot \mathrm{h}$; Wells and Taigen 1989), and three other North American hylids, Hyla cinerea, Hyla gratiosa, and Hyla squirella $\left(0.92,1.22\right.$, and $2.27 \mathrm{~mL} \mathrm{O}_{2} / \mathrm{g} \cdot \mathrm{h}$; Prestwich et al. 1989).

Oxygen consumption was not measured directly but was calculated from $\mathrm{CO}_{2}$ release. An error in this calculation may be caused by the use of an RQ shown by calling male Hyperolius marmoratus broadleyi, which is a closely related species with strong similarities both in behavior and physiology but one that nevertheless might catabolize different substrate combinations than does $H$. viridiflavus ommatostictus. An RQ of 0.8 is commonly used to calculate energy equivalents of ureotelic carnivores (Gessaman and Nagy 


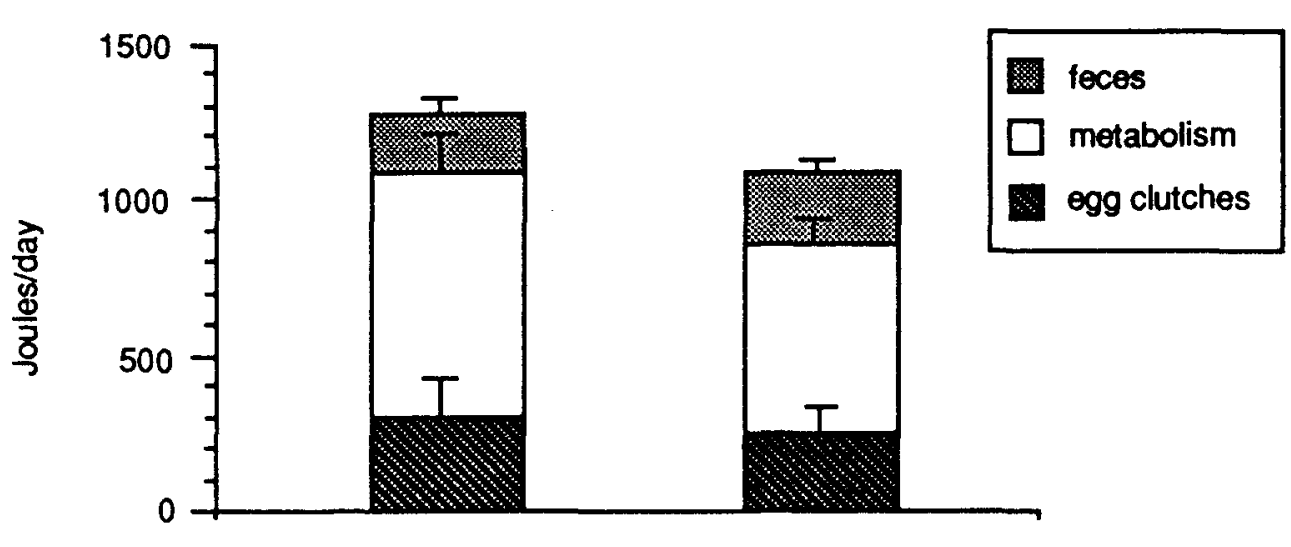

H. v. ommatostictus H. m. taeniatus

Fig. 2. Energy budgets of tbree Hyperolius viridiflavus (total of five clutches) and three Hyperolius marmoratus (total of nine clutches) females during the production of egg clutches. Measurements were conducted of gross energy uptake (total bar), energy content of feces (stippled region), and energy content of egg clutches produced in a few days (shaded region). Gross intake minus feces gives net intake. The difference between net intake and energy content of the clutch is energy expended for metabolism (unshaded). Data are given in J/d $\pm S D$.

1988). With this RQ instead of the 0.73 measured for $H$. marmoratus broadleyi (T. U. Grafe, unpublished data) $\mathrm{O}_{2}$ consumption at an average call rate of 5,400 calls/h would decrease by $9 \%$.

We calculated the unrestrained rate of $\mathrm{O}_{2}$ consumption with the regression equation in figure 1 . There are potential problems with predicting a value outside the range for which the regression has been calculated. However, this was the only way to obtain an estimate of $\mathrm{O}_{2}$ consumption at high call rates that are shown by unrestrained frogs, and the rate of $\mathrm{O}_{2}$ consumption while calling seems to be a linear function of calling rate for most species (Pough et al. 1992). Unfortunately, there are no data available on the call rate of unrestrained $H$. viridiflavus ommatostictus males in the field. It is likely that rates measured in the laboratory are higher than those in the field because frogs were kept at high densities and fed ad lib.

Rates of resting metabolism reported for $H$. viridiflavus ommatostictus and Hyperolius marmoratus taeniatus (table 1) are higher than those reported for H. viridiflavus ssp. (Taigen, Emerson, and Pough 1982; 0.094 $\mathrm{mL} \mathrm{O}_{2} / \mathrm{g} \cdot \mathrm{h}$ at $20^{\circ} \mathrm{C}$ ), Hyperolius marmoratus verucosus (Withers et al. $1982 ; 0.0671 \mathrm{~mL} \mathrm{O}_{2} / \mathrm{g} \cdot \mathrm{h}$ at $20^{\circ} \mathrm{C}$ ), and $\mathrm{H}$. marmoratus taeniatus (Geise $1987 ; 0.130 \mathrm{~mL} \mathrm{O} / \mathrm{g} \cdot \mathrm{h}$ at $25^{\circ} \mathrm{C}$ ). There are two possible reasons for this. First, in this study resting metabolism was measured during the night when 
TABLE 4

Changes in whole-body lipid content (\%) in adult Hyperolius marmoratus taeniatus during the course of a simulated breeding season

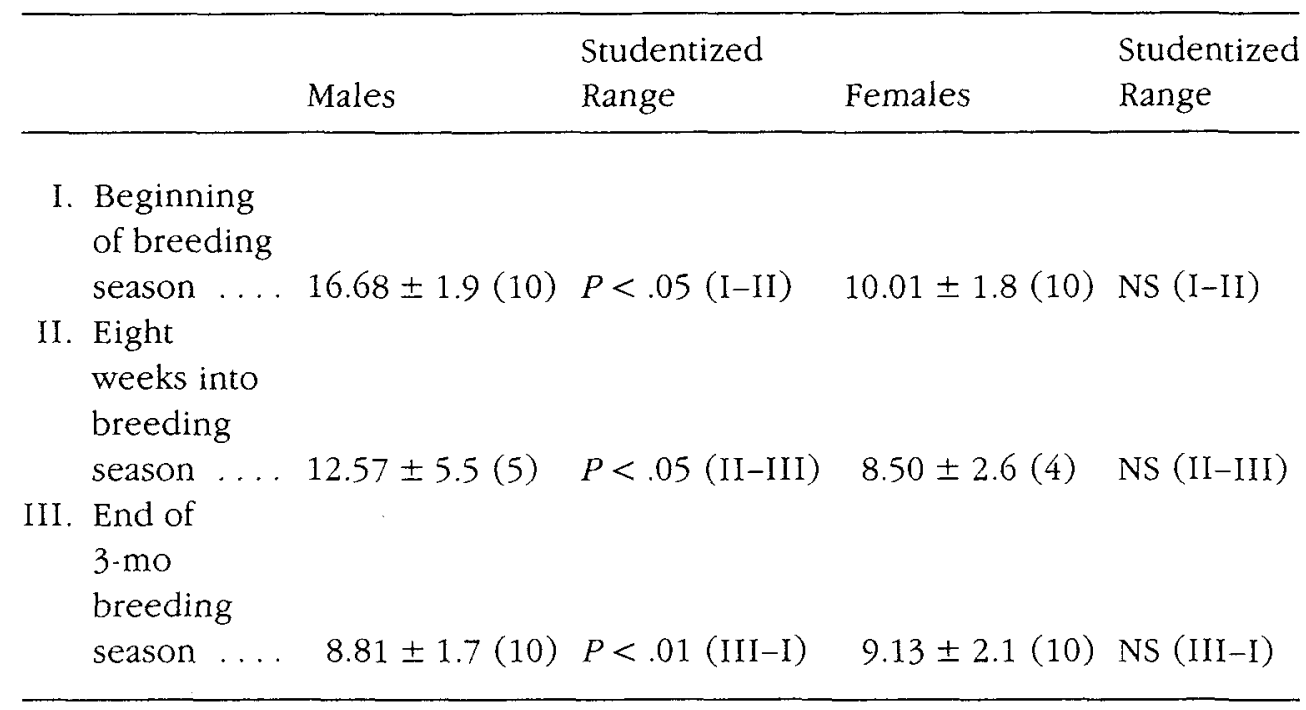

Note. Values are means \pm SD. Numbers in parentheses are sample sizes; $N S=$ not significant.

frogs were in a high mating disposition and showed a high readiness for activity. Since males were not exposed to a playback of a chorus during measurements, elevated levels of $\mathrm{O}_{2}$ consumption do not reflect a "stimulated" rate of $\mathrm{O}_{2}$ consumption as postulated by Ryan, Bartholomew, and Rand (1983). Second, in contrast to previous accounts, frogs were fed ad lib. prior to measurements. It is well-known that metabolic rate increases after feeding because of specific dynamic action (see, e.g., Seale 1987). In a plethodontid salamander species, for example, $\mathrm{O}_{2}$ consumption increased by $76 \%$ after feeding (Feder et al. 1984). For an estimation of energy expenditure during reproductive activity, measurements of metabolic rate in animals that could feed freely are more appropriate for estimates of incremental costs of calling than are standard rates obtained from fasting animals.

The incremental cost of calling can be calculated as $\left(\dot{\mathrm{V}}_{2 \text { call }}\right)-\left(\dot{\mathrm{V}}_{2 \text { rest }}\right)$ and $\mathrm{O}_{2}$ consumption converted to joules with a conversion factor of 20.08 $\mathrm{J} / \mathrm{mL} \mathrm{O}_{2}$ (Schmidt-Nielson 1979). Thus, a 1.5.g male H. viridiflavus ommatostictus would use $33 \mathrm{~J} / \mathrm{h}$.

In a comparison of five species of small frogs between 1 and $2 \mathrm{~g}$ body mass (mostly hylids), H. viridiflavus ommatostictus had exceptionally high energy expenditure per minute of calling (Pough et al. 1992). Pough et al. 
suggest that differences in muscle physiology may account for such differences in calling effort. This may reflect the different phylogenetic origin of the Hyperoliidae and Hylidae or might be due to behavioral or ecological differences selecting for different muscle architectures. Clearly, more comparative work is necessary especially on the muscle physiology of hyperoliid frogs.

Our data show that calling activity in $H$. viridiflavus ommatostictus was not dependent on anaerobic metabolism. Calling activity in most anurans seems to be sustained by muscles in the trunk region (Gans 1973; Taigen et al. 1985), whereas laryngeal muscles probably contribute only little to energetic costs of calling. Trunk muscles have been shown to have a high catabolic enzyme activity in $H$. crucifer (Taigen et al. 1985) and in $H$. versicolor (Marsh and Taigen 1987) in calling males.

Higher whole-body lactate concentrations in calling reed frogs than in those resting may be due to higher lactate levels in limb muscles used when frogs move to calling sites, move around between calling bouts, or engage in agonistic kicking contests with other males. No apparent difference between calling and resting frogs in lactate concentrations was found in the rest of the body, which included the trunk muscles, demonstrating that calling activity is not maintained by anaerobic metabolism. Prestwich et al. (1989) found a similar elevation in lactate in whole-body homogenates in ealling versus resting $H$. squirella. This was also due entirely to higher lactate concentrations in hind limbs of calling frogs and not to lactate ac cumulation in the trunk muscles. Using a different approach, Taigen and Wells (1985) showed that lactate levels drop in $H$. versicolor after several hours of calling. Anaerobic metabolism therefore does not play a noticeable role in supporting calling activity, and energy costs of calling can reliably be calculated from rates of $\mathrm{O}_{2}$ consumption.

Clearly, anaerobic metabolism contributes to other activities, probably during fighting, as demonstrated by elevated lactate levels in frogs after forced activity. Taigen et al. (1982) measured whole-body lactate in $\mathrm{H}$. viridiflavus ssp. after 4 min of activity in a metabolic chamber. Their mean value of $1.158 \mathrm{mg} / \mathrm{g}$ is only slightly higher than the mean value reported here (table 2).

\section{Energy Allocation}

Because of short between-clutch intervals, it was possible to determine assimilation $(A / C)$ and conversion $(P / A, P / C)$ efficiencies during the period of clutch production. Assimilation efficiencies of adult reed frogs are comparable to those of other amphibians (Fitzpatrick 1973; Burton and Likens 
1975; Smith 1976; Woolbright 1985). Differences in efficiencies are probably due to variability in digestibility and volume of prey, temperature at which measurements are conducted, and the hydration state of the animals. Assimilated energy not used for egg production is used for metabolism and for conversion of assimilated energy products into the corresponding components of vitellogenesis.

It is not clear why assimilation efficiencies of juvenile $H$. marmoratus taeniatus were lower than in adults. It is possible that all of the feces of juveniles were collected from the bare containers they were kept in, whereas some of the feces of adults may have been lost in the planted terraria. Also, feces collected from terraria could have been subject to some bacterial contamination because feces were not collected immediately after excretion. Thus $A / C$ of adults may be somewhat lower than table 3 indicates. Reed frogs could feed on a variety of different prey types and have different efficiencies as a result, and the data presented here must be viewed as restricted to those prey that were fed the frogs. Preliminary observations on $H$. marmoratus broadleyi at one locality indicate that soft-bodied insects make up the major portion of this frog's diet (T. U. Grafe, unpublished data), and assimilation efficiencies are likely to be similar in field populations of reed frogs.

Female amphibians can invest considerable amounts of energy into reproduction in the form of eggs, and this investment is generally calculated from the energy content of clutches. Investment per clutch varies considerably between species, with average values of $2.37-7.16 \mathrm{~kJ}$ in nine species of tropical hylids (Crump and Kaplan 1979), $3.96 \mathrm{~kJ}$ in P. pustulosus (Ryan et al. 1983), $6.83 \mathrm{~kJ}$ in Eleutherodactylus coqui (Woolbright 1985), and 3.38 $\mathrm{kJ}$ in the salamander Desmognathus ochrophaeus (Fitzpatrick 1973). Average investment per clutch correlates with clutch size, egg size, and possibly with mass-specific energy content. Both clutch and egg size were larger in $H$. viridiflavus ommatostictus than in $H$. marmoratus taeniatus leading to higher overall investments per clutch. As in other amphibians (Shine 1979), clutch sizes for both reed frogs were positively correlated with body size (Grafe 1988).

Data on seasonal investment and clutch intervals are difficult to collect in the field, and little is therefore known about the partitioning of reproductive effort in female amphibians under natural conditions (Duellman and Trueb 1985). The short intervals between clutches in the reed frogs investigated most probably reflect potential reproductive investment under ad lib. feeding conditions rarely encountered in the field and clutch intervals may be close to the physiological processing capacity of females. Telford and Dyson (1990) reported an average clutch interval of $57 \mathrm{~d}$ in a field population 
of Hyperolius marmoratus marmoratus, but this may be an overestimate because of the difficulty of finding all females that deposit eggs.

The magnitude of energy allocated to egg production relative to the total energy intake has hardly been considered. Fitzpatrick (1973) estimated the annual energy flow in $D$. ocbrophaeus for egg production and parental care to be 48\%. Fitzpatrick (1973), Burton and Likens (1975), and Smith (1976) give estimates of conversion efficiencies resulting in growth, but their values were obtained by subtracting resting metabolic costs $(M)$ from assimilated energy $(A ; P=A-M)$. Such calculations lead to unrealistically high values since $M$ is underestimated (Seale 1987).

No one before us has collected data on the actual proportion of energy invested in eggs by female amphibians. Our direct measurements of the proportion of energy allocated to egg production are expected to be lower in animals under field conditions in which foraging may be less successful and energy accrual may take longer, resulting in overall higher metabolic costs that divert energy from vitellogenesis. Data on energy uptake are essential for determining the costs of reproduction. Such costs can arise if reproductive investment occurs at the expense of growth or maintenance. Increased energy uptake during reproduction could offset increased energy requirements and reduce potential costs of reproduction (Hirschfield and Tinkle 1975; Tuomi, Hakala, and Haukioja 1983).

$\therefore$ It is surprising that the percent of whole-body lipid content did not decrease significantly in female $H$. marmoratus taeniatus over the course of the breeding season (table 4). This indicates that, at least under laboratory conditions, females can yolk up eggs without net depletion of fat deposits and are able to maintain a more balanced energy budget than males during the breeding season. Why did males kept under the same conditions not replenish fat stores? We think that males at the breeding aggregation may be in a different motivational status and may not feed as readily as females. At least in the laboratory, males of both reed frog species had lower intake rates than females (Schmuck 1989). Ryan (1985) reports significantly more empty stomachs in calling than in noncalling $P$. pustulosus. Likewise, re duced food intake was found in male $E$. coqui during the breeding season because they stay on the forest floor to call or attend to eggs (Woolbright 1985) and calling males are not apt to pursue potential prey as much as do noncalling males (Woolbright and Stewart 1987).

A reduction in fat body mass during the breeding season has been reported in many species of anurans at the population level (reviewed in Fitzpatrick 1976), but this has hardly been correlated with individual behavior. In contrast, fat body and carcass fat content did not decrease in females during reproduction in the salamander Amphiuma means apparently because of 
an extended period of vitellogenesis during which energy uptake parallels yolk production (Rose 1967).

Caution should be used in strongly linking energy budgets with potential costs of reproduction since energy budgets consider only the energy index. As MacNally (1981) has pointed out, the acquisition of essential nutrients such as minerals or vitamins could play a role in the time budgets of some amphibians. Indeed, since ectotherms are such efficient food converters (Pough 1983) they might ingest fewer nutrients than do endotherms and are more likely to be nutrient limited (Seale 1987). Unfortunately, little is known about specific dietary requirements of amphibians.

For a complete assessment of reproductive energetics in reed frogs and for a comparison of total energy expended for reproduction by males and females during a breeding season, field information is needed on prey availability, predation risk, chorus tenure of males, and rates of clutch production, as well as costs of egg deposition and mate searching by females. Nevertheless, this study gives a perspective on how high reproductive-investment patterns under optimal conditions are and it forms an important baseline for further investigations.

\section{Acknowledgments}

We thank Wolfgang Geise for valuable discussions during this study and Kraig Adler, Christopher Murphy, Harvey Pough, Marion Preest, and two anonymous reviewers for comments on the manuscript. This work was supported by the Deutsche Forschungsgemeinschaft grant Li 150/II-1,2.

\section{Literature Cited}

Bucher, T. L., M. J. Ryan, and G. A. Bartholomew. 1982. Oxygen consumption during resting, calling, and nest building in the frog Pbysalaemus pustulosus. Physiol. Zool. 55:10-22

Burton, T. M., and G. E. Likens. 1975. Energy flow and nutrient cycling in salamander populations in the Hubbard Brook Experimental Forest, New Hampshire. Ecology 56:1068-1080.

Crump, M. L., and R. H. Kaplan. 1979. Clutch energy partitioning of tropical tree frogs (Hylidae). Copeia 1979:625-635.

Dobush, G. R., C. D. Ankney, and D. G. Krementz. 1985. The effect of apparatus, extraction time, and solvent type on lipid extractions of snow geese. Can. J. Zool. 63:1917-1920.

Duellman, W. E., and L. Trueb. 1985. Biology of amphibians. McGraw-Hill, New York. 670 pp. 
Feder, M. E., A. G. GibBs, G. A. Griffith, and J. Tsujr. 1984. Thermal acclimation of metabolism in salamanders: fact or artifact? J. Therm. Biol. 9:255-260.

FitzPatrick, L. C. 1973. Energy allocation in the Allegheny Mountain salamander, Desmognathus ocbrophaeus. Ecol. Monogr. 43:43-58.

- 1976. Life history patterns of storage and utilization of lipids for energy in amphibians. Am. Zool. 16:725-732.

GANS, C. 1973. Sound production in the Salientia: mechanism and evolution of the emitter. Am. Zool. 15:1179-1194.

Geise, W. 1987. Leben unter Extrembedingungen: Untersuchungen zur Ästivationsphysiologie und zur Variabilität im Lebenszyklus beim afrikanischen Riedfrosch Hyperolius viridiflavus (Anura: Hyperoliidae). Ph.D. diss. Universität Würzburg. $155 \mathrm{pp}$.

Geise, W., and K. E. Linsenmair. 1986. Adaptations of the reed frog Hyperolius viridiflavus (Amphibia, Anura, Hyperoliidae) to its arid environment. II. Some aspects of the water economy of $H$. v. nitidulus under wet and dry season conditions. Oecologia 68:542-548.

- 1988. Adaptations of the reed frog Hyperolius viridiflavus (Amphibia, Anura, Hyperoliidae) to its arid environment. IV. Ecological significance of water economy with comments on thermoregulation and energy allocation. Oecologia 77:327338.

Gessaman, J. A., and K. A. NaGy. 1988. Energy metabolism: errors in gas-exchange conversion factors. Physiol. Zool. 61:507-513.

GIVEN, M. F. 1988. Growth rate and the cost of calling activity in male carpenter frogs, Rana virgatipes. Behav. Ecol. Sociobiol. 22:153-160.

GRAFE, T. U. 1988. Untersuchungen zur Fortpflanzungsbiologie und zu Lebensstrategien von Hyperolius viridiflavus (Amphibia, Anura, Hyperoliidae). Diplomarbeit. Universität Würzburg. 69 pp.

Halliday, T. R. 1987. Physiological constraints on sexual selection. Pages 247-264 in J. W. BRADBURY and M. B. ANDERSSON, eds. Sexual selection: testing the alternatives. Wiley, Chichester.

HIRSCHFIELD, M. F., and D. W. TiNKLE. 1975. Natural selection and the evolution of reproductive effort. Proc. Natl. Acad. Sci. USA 72:2227-2231.

KOBELT, F., and K. E. LinsENMAIR. 1986. Adaptations of Hyperolius viridiflavus (Amphibia, Anura, Hyperoliidae) to its arid environment. I. The skin of Hyperolius viridiflavus nitidulus (Laurent) in wet and dry season conditions. Oecologia 68: 533-541.

MACNALLY, R. C. 1981. On the reproductive energetics of chorusing males: energy depletion, restoration, and growth for two sympatric species of Ranidella (Anura). Oecologia 51:181-188.

MARSH, R. L., and T. L. TAIGEN. 1987. Properties enhancing aerobic capacity of calling muscels in gray treefrogs Hyla versicolor. Am. J. Physiol. 252:R786-R793.

MAYNARD SmITH, J. 1958. The theory of evolution. Penguin, Harmondsworth.

PASSmoRe, N. J. 1981. Sound levels of mating calls of some African reed frogs. Herpetologica 37:166-171.

Pougr, F. H. 1983. Amphibians and reptiles as low energy systems. Pages 141-188 in W. P. AsPeY and S. I. Lustick, eds. Behavioral energetics. Ohio State University Press, Columbus. 
1989. Organismal performance and darwinian fitness: approaches and interpretations. Physiol. Zool. 62:199-236.

Pough, F. H., W. E. Magnusson, M. J. Ryan, T. T. Tajgen, and K. D. Wells. 1992. Behavioral energetics. In M. E. FEDER and W. W. BURGGREN, eds. Environmental physiology of the amphibians. University of Chicago Press, Chicago.

Poynton, J. C. 1985. On the Hyperolius marmoratus complex (Anura). S. Afr. J. Sci. 81:179-181.

Poynton, J. C., and D. G. Broadley. 1987. Amphibia Zambesiaca. 3. Rhacophoridae and Hyperoliidae. Ann. Natal Mus. 28:161-229.

Prestwich, K. N., K. E. Brugger, and M. Topping. 1989. Energy and communication in three species of hylid frogs: power output and efficiency. J. Exp. Biol. 144:5380.

Richards, C. M. 1977. Reproductive potential under laboratory conditions of $H y$. perolius viridiflavus (Amphibia, Anura, Hyperoliidae), a Kenyan reed frog. J. Herpetol. 11:426-428.

Robertson, J. G. M. 1986. Male territoriality, fighting and assessment of fighting ability in the Australian frog Uperoleia rugosa. Anim. Behav. 34:763-772.

Rose, F. L. 1967. Seasonal changes in lipid levels of the salamander Amphiuma means. Copeia 1967:662-666.

RYAN, M. J. 1985. The tungara frog: a study in sexual selection and communication. University of Chicago Press, Chicago. $230 \mathrm{pp}$.

Ryan, M. J., G. A. Bartholomew, and A. S. Rand. 1983. Energetics of reproduction in a neotropical frog, Physalaemus pustulosus. Ecology 64:1456-1462.

SCHIøTz, A. 1971. The superspecies Hyperolius viridiflavus (Anura). Vidensk. Medd. Dan. Naturhist. Foren. 134:21-76.

- 1975. The treefrogs of eastern Africa. Steenstrupia, Copenhagen. 232 pp.

Schmidt-Nielson, K. 1979. Animal physiology. Cambridge University Press, Cambridge. $560 \mathrm{pp}$.

SCHMUCK, R. 1989. Ökophysiologie afrikanischer Riedfrösche: Besiedlung extremer Lebensräume. Ökologie in Forschung und Anwendung. Vol. 3. Margraf, Weikersheim. 208 pp.

Schmuck, R., F. Kobelt, and K. E. Linsenmair. 1988. Adaptations of the reed frog Hyperolius viridiflavus (Amphibia, Anura, Hyperoliidae) to its arid environment. V. Iridophores and nitrogen metabolism. J. Comp. Physiol. 158B:537-546.

SCHMUCK, R., and K. E. Linsenmair. 1988. Adaptations of the reed frog Hyperolius viridiflavus (Amphibia, Anura, Hyperoliidae) to its arid environment. III. Aspects of nitrogen metabolism and osmoregulation in the reed frog, Hyperolius viridiflavus taeniatus, with special reference to the role of iridophores. Oecologia 75 : 354-361.

Seale, D. B. 1987. Amphibia. Pages 467-552 in F. J. Vernberg and T. J. Pandian, eds. Animal energetics. Vol. 2. Academic Press, New York.

SHine, R. 1979. Sexual selection and sexual dimorphism in the Amphibia. Copeia 1979:297-306.

SMITH, G.C. 1976. Ecological energetics of three species of ectothermic vertebrates. Ecology 35:1142-1148.

SNEDECOR, G. W., and W. G. Cochran. 1980. Statistical methods. Iowa State University Press, Ames. 507 pp. 
StEaRns, S. C. 1976. Life history tactics: a review of the ideas. Q. Rev. Biol. 51:3-47. STEWarT, M. M. 1967. Amphibians of Malawi. State University of New York Press, Albany. 163 pp.

TAIgen, T. L., S. B. Emerson, and F. H. Pough. 1982. Ecological correlates of anuran exercise physiology. Oecologia 52:49-56.

TAIGEN, T. L., and K. D. WELLS. 1985. Energetics of vocalization by an anuran amphibian (Hyla versicolor). J. Comp. Physiol. 155:163-170.

TAIGEN, T. L., K. D. Wells, and R. L. Marsh. 1985. The enzymatic basis of high metabolic rates in calling frogs. Physiol. Zool. 58:719-726.

TELFORD, S. R. 1985. Mechanisms and evolution of inter-male spacing in the painted reedfrog (Hyperolius marmoratus). Anim. Behav. 33:1353-1361.

TELFoRD, S. R., and M. L. Dyson. 1990. The effect of rainfall on interclutch interval in painted reed frogs (Hyperolius marmoratus). Copeia 1990:644-648.

Trivers, R. L. 1972. Parental investment and sexual selection. Pages 136-179 in B. Cambell, ed. Sexual selection and the descent of man. Aldine, Chicago.

TuOmi, J., T. HaKala, and E. Haukioja. 1983. Alternative concepts of reproductive efforts, costs of reproduction, and selection in life history evolution. Am. Zool. 23:25-34.

WAGER, V. A. 1965. The frogs of South Africa. Purnell, Cape Town. $242 \mathrm{pp}$.

WeLLS, K. D. 1977. The social behavior of anuran amphibians. Anim. Behav. 25:666693.

WELLS, K. D., and T. L. TAIGEN. 1989. Calling energetics of a Neotropical treefrog, Hyla microcephala. Behav. Ecol. Sociobiol. 25:13-22.

Withers, P. C., G. Louw, and S. Nicholson. 1982. Water loss, oxygen consumption and colour change in "waterproof" reed frogs (Hyperolius). S. Afr. J. Sci. 78:3032.

Woolbright, L. L. 1985. Sexual dimorphism in body size of the subtropical frog Eleutherodactylus coqui. Ph.D. diss. State University of New York at Albany. 127 pp.

WOOLBRIGHT, L. L., and M. M. STEWART. 1987. Foraging success of the tropical frog, Eleutberodactylus coqui: the cost of calling. Copeia 1987:69-75. 